\title{
Letter to the Editor: Oral risedronate
} increases Gruen zone bone mineral density after primary total hip arthroplasty: a meta-analysis

\author{
Kai Huang ${ }^{1,2}$, Gang Wang ${ }^{1,2}$ and Yi Zeng ${ }^{1,2^{*}}$
}

\section{Dear editors,}

Recently, we read a meta-analysis by Li et al. [1] entitled "Oral risedronate increases Gruen zone bone mineral density after primary total hip arthroplasty: a meta-analysis" with great interest. Periprosthetic bone loss after total hip arthroplasty is an inevitable phenomenon mainly due to stress shielding, which may predispose to aseptic loosening, periprosthetic fractures and challenges at revision surgery. We appreciate the authors' work in this field, however, some issues in the article that may nullify the conclusion need to be mentioned.

Firstly, the authors declared that they had systematically retrieved electronic databases including PubMed, Embase, Web of Science, Cochrane Library, and Chinese Wanfang database. However, to our knowledge, a study by Yin et al. [2] in Wanfang database was eligible on the basis of inclusion criteria, which could be involved in this meta-analysis and beneficial to draw a more comprehensive and convincing conclusion.

Secondly, we noticed that four of the included studies with short-term follow-up (6-12 months) revealed significant efficacy of risedronate while the left one with relatively longer follow-up (4 years) drew the exact opposite conclusion. Although these studies showed excellent

\footnotetext{
*Correspondence: zengyigd@126.com

${ }^{1}$ Department of Orthopaedics and National Clinical Research Center for Geriatrics, Orthopaedic Research Institute, West China Hospital,

Sichuan University, 37 Guoxue Road, Chengdu, Sichuan Province 610041, People's Republic of China

Full list of author information is available at the end of the article
}

homogeneousness, it was improper to ignore the potential reasons for such difference and simply put them into pooled analysis, which without any doubt would bring extra bias and lead to an incorrect conclusion.

Thirdly, it is obvious that two of the included studies (Skoldenberg, 2011 and Kumar, 2011) were the same article. What's more, both of them and Muren et al. [3] came from the same clinical cohort. Thus, extracting duplicate data from these three articles for analysis would be more likely to lead to an incorrect conclusion and misleading clinical practice. Given that four of the eligible RCTs were followed up no more than 1 year except Muren et al. (4-year follow-up), we recommend to rule out Muren et al. and conduct a short-term ( $\leq 1$ year) meta-analysis in a reference of the work by Shi et al. [4]. Details of these eligible studies are shown in Table 1.

Fourthly, we find that there are another four similar meta-analyses published online in 2018 [5-8]. All of them were performed following the guideline of PRISMA and four declared that they were the first meta-analysis on this topic, while none of them had a protocol registration in any platform, such as the Cochrane Library and PROSPERO. The meta-analysis registration is very essential to not only improve the quality of reporting, but also provide transparency and avoid repetitive publications.

Finally, it is not rigorous and persuasive enough for authors to conclude that risedronate could significantly reduce periprosthetic bone loss around an uncemented femoral stem, for the long-standing drug efficacy on periprosthetic bone loss and the benefit of final prognosis original author(s) and the source, provide a link to the Creative Commons licence, and indicate if changes were made. The images or other third party material in this article are included in the article's Creative Commons licence, unless indicated otherwise in a credit line to the material. If material is not included in the article's Creative Commons licence and your intended use is not permitted by statutory regulation or exceeds the permitted use, you will need to obtain permission directly from the copyright holder. To view a copy of this licence, visit http://creativecommons.org/licenses/by/4.0/. The Creative Commons Public Domain Dedication waiver (http://creativeco mmons.org/publicdomain/zero/1.0/) applies to the data made available in this article, unless otherwise stated in a credit line to the data. 
Table 1 Baseline characteristic of four eligible studies not include Muren et al. and Kumar et al. in the meta-analysis

\begin{tabular}{|c|c|c|c|c|c|c|c|c|c|}
\hline \multirow[t]{2}{*}{ Studies } & \multirow[t]{2}{*}{ Year } & \multirow[t]{2}{*}{ Study design } & \multirow[t]{2}{*}{ Country } & \multirow{2}{*}{$\begin{array}{l}\text { No. of patients } \\
\text { (E/P) }\end{array}$} & \multirow{2}{*}{$\begin{array}{l}\text { Mean age } \\
(E / P)\end{array}$} & \multirow{2}{*}{$\begin{array}{l}\text { Female patients } \\
(E / P)\end{array}$} & \multicolumn{2}{|l|}{ Interventon } & \multirow[t]{2}{*}{ Follow up } \\
\hline & & & & & & & Experimental & Placebo & \\
\hline Kinov & 2005 & RCT & Bulgaria & $12 / 12$ & $58.3 / 56$ & $8 / 7$ & $35 \mathrm{mg}$ risedronate & Placebo & 6 months \\
\hline Yamasaki & 2006 & RCT & Japan & $19 / 21$ & $66.8 / 66.7$ & $17 / 19$ & $2.5 \mathrm{mg} / \mathrm{d}$ risedronate & Placebo & 6 months \\
\hline Skoldenberg & 2011 & RCT & Sweden & $36 / 37$ & $61.2 / 60.3$ & $22 / 21$ & 35 mg risedronate & Placebo & 1 year \\
\hline Yin & 2013 & RCT & China & $13 / 13$ & $61.5 / 63.7$ & $5 / 6$ & $5 \mathrm{mg} / \mathrm{d}$ risedronate & Placebo & 6 months \\
\hline
\end{tabular}

RCT: Randomized controlled trial, E: Experimental, P: Placebo

are still inconclusive. Larger clinical trials that focus on clinically relevant endpoints with a longer duration of follow-up are warranted.

\section{Abbreviations}

RCT: Randomized Controlled Trial; PRISMA: Preferred Reporting Items for Systematic Reviews and Meta-Analyses.

\section{Acknowledgements}

Not applicable.

\section{Authors Contributions}

Kai Huang and Gang Wang conceived the study; Kai Huang wrote and edited the paper; Yi Zeng read and approved the final manuscript.

\section{Funding}

Not applicable.

\section{Availability of data and materials \\ Not applicable.}

\section{Declarations}

Ethics approval and consent to participate

Not applicable.

\section{Consent for publication}

Not applicable.

\section{Competing interests}

The authors declare that they have no competing interests.

\section{Author details}

${ }^{1}$ Department of Orthopaedics and National Clinical Research Center for Geriatrics, Orthopaedic Research Institute, West China Hospital, Sichuan University, 37 Guoxue Road, Chengdu, Sichuan Province 610041, People's Republic of China. ${ }^{2}$ Laboratory of Stem Cell and Tissue Engineering, Orthopaedic Research Institute, West China Hospital, Sichuan University, Chengdu 610041, People's Republic of China.

Received: 25 October 2021 Accepted: 15 December 2021

Published online: 05 January 2022

\section{References}

1. Li Q, Xu B. Oral risedronate increases Gruen zone bone mineral density after primary total hip arthroplasty: a meta-analysis. J Orthop Surg Res. 2018;13(1):144. https://doi.org/10.1186/s13018-018-0794-1.

2. Yin P, Yao Y, Cui LH, et al. Effect of risedronate on early postoperative periprosthetic bone mineral density of the proximal femur after cementless total hip arthroplasty. Chin J Osteoporosis. 2013;19:732-6 (Chinese).
3. Muren $\mathrm{O}$, Akbarian E, Salemyr M, et al. No effect of risedronate on femoral periprosthetic bone loss following total hip arthroplasty. A 4-year followup of 61 patients in a double-blind, randomized placebo-controlled trial. Acta Orthop. 2015;86:569-74. https://doi.org/10.3109/17453674.2015. 1041846.

4. Shi J, Liang G, Huang R, Liao L, Qin D. Effects of bisphosphonates in preventing periprosthetic bone loss following total hip arthroplasty: a systematic review and meta-analysis. J Orthop Surg Res. 2018;13(1):225. https://doi.org/10.1186/s13018-018-0918-7.

5. Su J, Wei Y, Li XM, Diao YP, Liu HG, Zhang L. Efficacy of risedronate in improving bone mineral density in patients undergoing total hip arthroplasty: a meta-analysis of randomized controlled trials. Medicine (Baltimore). 2018;97(51):e13346. https://doi.org/10.1097/MD.0000000000 013346.

6. Ren L, Wang W. Effect of risedronate on femoral periprosthetic bone loss following total hip replacement: a systematic review and meta-analysis. Medicine (Baltimore). 2018;97(17):e0379. https://doi.org/10.1097/MD. 0000000000010379.

7. Yang $L$. The efficiency of risedronate in reducing bone resorption after total hip arthroplasty: a meta-analysis of randomized control trials at a minimum of 6 months' follow-up. J Orthop Surg Res. 2018;13(1):88. https://doi.org/10.1186/s13018-018-0808-z.

8. Wang $M$, Wang $L$, Ye R. Risedronate reduces postoperative bone resorption after cementless total hip arthroplasty: a systematic review and meta-analysis. Int J Surg. 2018;52:189-200. https://doi.org/10.1016/j.ijsu. 2018.02.007.

\section{Publisher's Note}

Springer Nature remains neutral with regard to jurisdictional claims in published maps and institutional affiliations.

Ready to submit your research? Choose BMC and benefit from:

- fast, convenient online submission

- thorough peer review by experienced researchers in your field

- rapid publication on acceptance

- support for research data, including large and complex data types

- gold Open Access which fosters wider collaboration and increased citations

- maximum visibility for your research: over $100 \mathrm{M}$ website views per year

At BMC, research is always in progress.

Learn more biomedcentral.com/submissions 